\title{
Physiological responses of a marine planktonic diatom to transitions in growth irradiance
}

\author{
Anton F. Post ${ }^{1}$, Zvy Dubinsky ${ }^{2}$, Kevin Wyman ${ }^{3}$, \& Paul G. Falkowski ${ }^{3}$ \\ ${ }^{1}$ Laboratorium voor Microbiologie, University of Amsterdam, Nieuwe Achtergracht 127, 1018 WS Amsterdam, \\ The Netherlands \\ 2 Department of Life Sciences, Bar-Ilan University, Ramat-Gan, Israel \\ ${ }^{3}$ Brookhaven National Laboratory, Oceanographic Sciences Div., Upton, New York 11973, USA
}

\begin{abstract}
The time course of adaptation to changes in growth irradiance was studied in the marine diatom Thalassiosira weisflogii. Irradiance changes were from 72 to $593 \mu \mathrm{E} \mathrm{m}^{-2} \mathrm{~s}^{-1}(\mathrm{~L} \rightarrow \mathrm{H}$ ) and from 593 to $72 \mu \mathrm{E} \mathrm{m}^{-2} \mathrm{~s}^{-1}(\mathrm{H} \rightarrow \mathrm{L})$. In steady state, high-light (HL) grown cells were characterized by low pigment contents and a low in vivo absorbance. Light saturated photosynthesis, expressed on a per cell basis, was higher for low-light (LL) cells, but on a Chl a basis photosynthesis of HL cells was higher. $\mathrm{PSU}_{\mathrm{O}_{2}}$ sizes were not significantly different for $\mathrm{HL}$ and LL cells. In both transient states the carbohydrate pool was most dynamic and responded fastest to a change in irradiance. It was concluded that the carbohydrate pool serves as an energy and carbon reservoir buffering the cells from changes in irradiance and allowing other cellular properties to adjust to the new situation. The timescales of changes in $\mathrm{Chl} \mathrm{a} \mathrm{cell}{ }^{-1}$ and photosynthetic activities differed considerably: by a factor of 3 in the $\mathrm{L} \rightarrow \mathrm{H}$ transition and by a factor of 30 in the $\mathrm{H} \rightarrow \mathrm{L}$ transition. Irradiance transitions did not lead to marked changes in protein cell ${ }^{-1}$.
\end{abstract}

\section{INTRODUCTION}

The adaptation to growth irradiance in unicellular algae encompasses changes in many physiological functions (for reviews see Falkowski 1980, Richardson et al. 1983). During the adaptation process (i.e. in the transition from one steady-state growth rate to another brought about solely by changes in irradiance level), some of the general cellular processes or properties which change markedly include division rate, photosynthetic capacity, cellular pigmentation and respiration rate (Marra 1980, Prezelin \& Matlick 1980, Falkowski 1984a, Post et al. 1984). In the marine diatom Thalassiosira weisflogii (Grunow) Fryxell Hasle, the rate of adaptation to a new irradiance level depends upon whether the change is from a higher to lower irradiance or vice versa. Furthermore, the rates of change for different physiological responses (e.g. chlorophyll content, growth rate) do not necessarily parallel each other (Post et al. 1984).

We undertook to study the physiological responses of growth-irradiance adaptation by following the time course of changes in light-harvesting and photosynthetic properties as well as changes in pigment, carbo- hydrate and protein pools in Thalassiosira weisflogii. We reasoned that, as a first approximation, those processes or properties which changed first in response to changes in irradiance levels are physiologically linked to processes or properties which change later and so on. By following the kinetics of these processes or properties we could establish a 'cascade' of events which could lead to a clearer understanding of the molecular mechanisms involved in adaptation to growth irradiance.

Growth-irradiance adaptation may affect light-utilization efficiency $(\alpha)$ as well as the maximal rate of photosynthesis. During a transition from one growth irradiance level to another there may be a mismatch between growth rate and carbon fixation. During a low- to high-light transition, for example, a cell may fix 'excess' carbon (i.e. carbon over and above that needed to maintain its former steady-state growth rate). This carbon might be directed towards carbohydrate, lipid or protein pools. Therefore, it seems likely that during photoadaptation cellular pool sizes of (for example) carbohydrates and proteins respond to a change in light irradiance. The concept of 'overflow metabolism' (e.g. Myers 1980) like photorespiration (Tolbert 1974) 
and enhanced dark respiration (Falkowski et al. 1985) has evolved from short-term transient studies at high light. During adaptation to conditions of low light, division can proceed at the expense of reserve polymers (Loogman 1982), thereby buffering the cell from the effects of relatively fast changes in irradiance levels.

In this paper we examine how light-harvesting efficiency, photosynthetic activity and cellular pool sizes of carbohydrates and proteins respond to changes in growth irradiance. Changes in cellular pigment levels and division rates during light-shade adaptation in marine phytoplankters have been shown to obey first order kinetics (Falkowski 1980, 1984a, Rivkin et al. 1982a, Post et al. 1984). We investigated (1) whether changes in other cellular properties and processes followed similar kinetics, and (2) the sequence of response of the aforementioned variables to changes in growth irradiance.

\section{MATERIALS AND METHODS}

Thalassiosira weisflogii, clone T-VIC, was grown in a 3.21 continuous culture vessel in natural seawater, enriched with $F / 2$ nutrients (Guillard \& Ryther 1962) at $18^{\circ} \mathrm{C}$. The culture was operated in a turbidostat mode as described by Post et al. (1984). Continuous illumination was provided by 2 banks of three $32 \mathrm{~W}$, cool-white HO fluorescent tubes (Sylvania F24 T12). Growth irradiance was adjusted by switching on various combinations of tubes and changing the distance between the light banks and the turbidostat. Vessel irradiance was measured as scalar PAR with a $4 \pi$ quantum sensor (Biospherical Instruments QSL 100) in the center of the water filled turbidostat. Irradiances used were $72 \mu \mathrm{E}$ $\mathrm{m}^{-2} \mathrm{~s}^{-1}$ (LL) and $593 \mu \mathrm{E} \mathrm{m}^{-2} \mathrm{~s}^{-1}$ (HL). Changes in irradiance were made in a 1-step operation, either low to high ( $\mathrm{LL} \rightarrow \mathrm{HL}$ ) or high to low ( $\mathrm{HL} \rightarrow \mathrm{LL}$ ).

Cell numbers were estimated with a Coulter Counter, model TA II, after a $1: 20$ dilution in filtered seawater. Chlorophylls $a$ and $c$ were determined spectrophotometrically on an Aminco DW 2a spectrophotometer. Thirty ml of cells were filtered on Gelman AE glass fiber filters and pigments were extracted by grinding in $90 \%$ acetone. Chlorophyll $a$ and c concentrations were calculated according to Jeffrey \& Humphrey (1975). The spectrally averaged optical absorption cross-section normalized to $\mathrm{Chl} a, \mathrm{k}_{\mathrm{c}}$ (Atlas \& Bannister 1980, Dubinsky et al. 1984), was derived from in vivo absorption spectra, as described by Dubinsky et al. (1985).

Proteins were determined on $20 \mathrm{ml}$ aliquots after washing and 5-fold concentration using the Bradford procedure (Bradford 1976). Protein concentrations were measured spectrophotometrically at $595 \mathrm{~nm}$ in
$1 \mathrm{~cm}$ cuvettes using serum albumin standards. For the determination of total carbohydrates $10 \mathrm{ml}$ aliquots were washed and concentrated 10-fold. Carbohydrate concentrations were measured at $625 \mathrm{~nm}$ in $1 \mathrm{~cm}$ cuvettes against a D-glucose standard using anthrone reagent in $96 \% \mathrm{H}_{2} \mathrm{SO}_{4}$ according to Herbert et al. (1971).

Photosynthetic activities were measured with a Clark type electrode (YSI 5331) and a multigain amplifier as described by Dubinsky et al. (1985). The initial slope of the P vs I plots, $\alpha$, and the photosynthetic capacity, $P_{\max }$, were derived from a hyperbolic tangent fit (Jassby \& Platt 1976) through 12 or more data points. Oxygen flash yields $\left(\mathrm{PSU}_{\mathrm{O}_{2}}\right)$ were measured with repetitive short $(<3 \mu \mathrm{s}$ ) xenon flashes (GenRad Stroboslave 1539A) with a Rank Brothers electrode as described by Falkowski et al. (1981). The minimal turnover time for $\mathrm{O}_{2}$ evolution at light saturation, $\tau_{\text {, }}$ was calculated from $\mathrm{PSU}_{\mathrm{O}_{2}}$ and steady-state $\mathrm{P}_{\max }$ normalized to chlorophyll a (Myers \& Graham 1971, Falkowski et al. 1981).

For electron microscopy, cells were harvested by centrifugation and fixed in $3 \%$ glutaraldehyde buffered with $50 \mathrm{mM} \mathrm{Na-cacodylate,} \mathrm{pH} 7.4$, dehydrated in an acetone/water series and embedded in Epon. The cells were sectioned with a diamond knife and examined with a Phillips 300 transmission electron microscope.

Abbreviations used in this paper are listed in Table 1

\section{RESULTS}

The $\mathrm{P}$ vs I curves at steady state $\mathrm{HL}$ and LL conditions expressed on a per cell and per Chl a basis are presented in Fig. 1. On a cellular basis photosynthetic activities of Thalassiosira weisflogii were higher over the whole range of light intensities for LL cells (Fig. 1a). When photosynthesis was normalized to $\mathrm{Chl} \mathrm{a}$, however, the reverse was true (Fig. 1b). After a 1 -step change in light irradiance both cell division rates and $\mathrm{Chl} \mathrm{a}$ cell ${ }^{-1}$ changed gradually over time. Cell division rates were maximal $\left(2.3 \operatorname{div~d}^{-1} ; \mu=\right.$ $\left.1.59 \mathrm{~d}^{-1}\right)$ at $593 \mu \mathrm{E} \mathrm{m}^{-2} \mathrm{~s}^{-1}(\mathrm{HL})$, while growth was light limited $\left(0.7 \mathrm{div} \mathrm{d}^{-1} ; \mu=0.49 \mathrm{~d}^{-1}\right)$ at $72 \mu \mathrm{E}$ $\mathrm{m}^{-2} \mathrm{~s}^{-\mathrm{t}}(\mathrm{LL})$. At LL Chl a cell-1 was $9.2 \mathrm{pg} \mathrm{cell}^{-1}$ and under $\mathrm{HL}$ conditions it decreased to $4.3 \mathrm{pg} \mathrm{cell}^{-1}$ (Table 2) (see Post et al. 1984 for detailed discussion). Lower Chl a contents at HL were accompanied by a slightly higher $\mathrm{Chl}$ a/c ratio: $8.7 \pm 0.2$ (mole/mole) versus $7.5 \pm 0.4$ at $\mathrm{LL}$. Photosynthetic activity per cell at culture light intensity (i.e. the photosynthetic performance) was higher for HL cells than LL cells.

$\mathrm{PSU}_{\mathrm{O}_{2}}$ sizes, the so-called Emerson and Arnold numbers, were 1,840 $\pm 84 \mathrm{Chl}$ a/ $\mathrm{O}_{2}$ for $\mathrm{LL}$ and $2,115 \pm 153$ 
Table 1. List of abbreviātions

\begin{tabular}{|c|c|c|}
\hline LL & Low-light growth irradiance & $\mu E m^{-2} s^{-1}$ \\
\hline HL & High-light growth irradiance & $\mu \mathrm{E} \mathrm{m}^{-2} \mathrm{~s}^{-1}$ \\
\hline $\mathrm{L} \rightarrow \mathrm{H}$ & Transition from low to high light & - \\
\hline $\mathrm{H} \rightarrow \mathrm{L}$ & Transition from high to low light & - \\
\hline Chl a & Chlorophyll a & - \\
\hline Chl protein & Chlorophyll protein complex & - \\
\hline PS I & Photosystem I & \\
\hline PS II & Photosystem II & \\
\hline$\overline{\mathrm{k}}_{\mathrm{c}}$ & $\begin{array}{l}\text { The Chl a specific, spectrally averaged, } \\
\text { light attenuation coefficient }\end{array}$ & $\mathrm{m}^{2}(\mathrm{mg} \mathrm{Chl} a)^{-1}$ \\
\hline$\alpha$ & Light utilization efficiency on a per cell basis & $\mu \mathrm{mol} \mathrm{O}_{2} \mathrm{cell}^{-1} \mathrm{~min}^{-1} / \mu \mathrm{E} \mathrm{m}^{-2} \mathrm{~s}^{-1}$ \\
\hline$\alpha^{\prime}$ & Light utilization efficiency on a per Chl a basis & $\mu \mathrm{mol} \mathrm{O} \mathrm{O}_{2}(\mathrm{mg} \mathrm{Chl} \mathrm{a})^{-1} \mathrm{~min}^{-1} / \mu \mathrm{E} \mathrm{m}^{-2} \mathrm{~s}^{-1}$ \\
\hline$P_{\max }$ & $\begin{array}{l}\text { Photosynthetic capacity measured at } \\
\text { saturating light irradiances }\end{array}$ & $\mu \mathrm{mol} \mathrm{O}_{2}(\mathrm{mg} \mathrm{Chl} \mathrm{a})^{-1} \mathrm{~min}^{-1}$ \\
\hline $\mathrm{PSU}_{\mathrm{O}_{2}}$ & $\begin{array}{l}\text { Photosynthetic unit based on oxygen flash yields } \\
\left(\mathrm{Chl} a / \mathrm{O}_{2}\right)\end{array}$ & mole/mole \\
\hline ATP & Adenosine triphosphate & - \\
\hline NADPH & $\begin{array}{l}\text { Reduced nicotinamide adenine } \\
\text { dinucleotide phosphate }\end{array}$ & - \\
\hline mRNA & Messenger Ribonucleic acid & - \\
\hline RUBPcase & Ribulose 1,5-bisphosphate carboxylase & - \\
\hline$\tau$ & $\begin{array}{l}\text { The minimum time for } 4 \text { electrons to pass through } \\
\text { a PSU } \mathrm{O}_{2} \text {, from } \mathrm{H}_{2} \mathrm{O} \text { to PS I, measured at light } \\
\text { saturation }\end{array}$ & $\mathrm{ms}$ \\
\hline$\mu$ & Specific growth rate & $d^{-1}$ \\
\hline
\end{tabular}
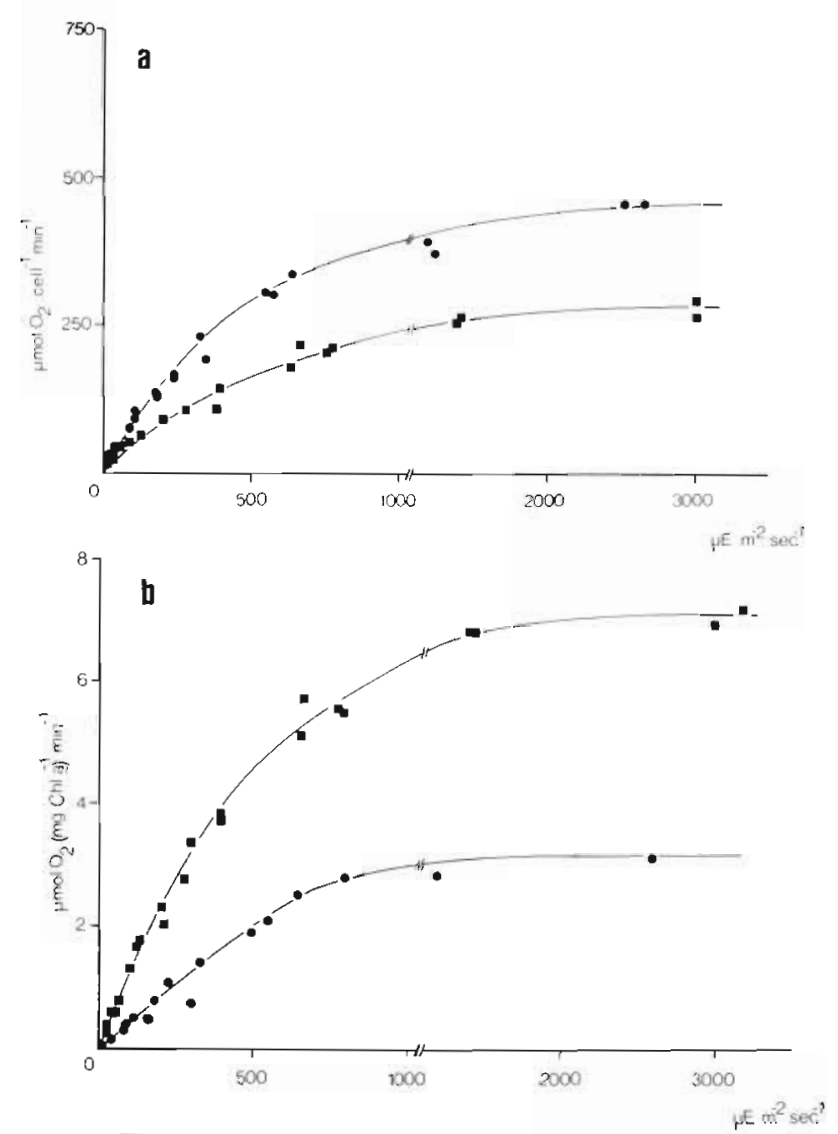

Fig. 1. Thalassiosira weisflogii. Photosynthesis-light curves when grown at $72 \mu \mathrm{E} \mathrm{m}^{-2} \mathrm{~s}^{-1}$ (•) and $593 \mu \mathrm{E} \mathrm{m}^{-2} \mathrm{~s}^{-1}$ (ロ) expressed on a per cell basis (a) and on a per Chl a basis (b)
Table 2. Thalassiosira weisflogii. Steady-state values and first-order rate constants for various parameters before and after a change in growth irradiance level at $17^{\circ} \mathrm{C}$

\begin{tabular}{|c|c|c|c|c|}
\hline \multirow{2}{*}{$\begin{array}{l}\text { Process } \\
\text { variable }\end{array}$} & \multicolumn{2}{|c|}{ Steady-state } & \multicolumn{2}{|c|}{ Transition rate $\left(\mathrm{h}^{-1}\right)$} \\
\hline & $\mathrm{HL}$ & LL & $\mathrm{L} \rightarrow \mathrm{H}$ & $\mathrm{H} \rightarrow \mathrm{L}$ \\
\hline Carbohydrates & $137^{\mathrm{a}}$ & $24^{\mathrm{a}}$ & +0.687 & -0.309 \\
\hline Chl a & $4.3^{\mathrm{a}}$ & $9.2^{\mathrm{a}}$ & -0.081 & +0.005 \\
\hline Protein & $120^{\mathrm{a}}$ & $119^{a}$ & - & - \\
\hline$\overline{\mathrm{k}}_{\mathrm{c}}$ & $0.0058^{b}$ & $0.0038^{b}$ & +0.067 & -0.039 \\
\hline$\mu$ & $1.59^{c}$ & $0.49^{c}$ & +0.081 & -0.510 \\
\hline$\alpha^{\prime}$ & $0.0095^{d}$ & $0.0048^{d}$ & - & - \\
\hline$a$ & $0.41^{e}$ & $0.59^{e}$ & -0.275 & +0.166 \\
\hline$\tau$ & $4.5^{f}$ & $9.8^{1}$ & -0.170 & +0.090 \\
\hline $\mathrm{PSU}_{\mathrm{O}_{2}}$ & $2115^{g}$ & $1840^{\mathrm{g}}$ & - & - \\
\hline \multicolumn{5}{|c|}{ 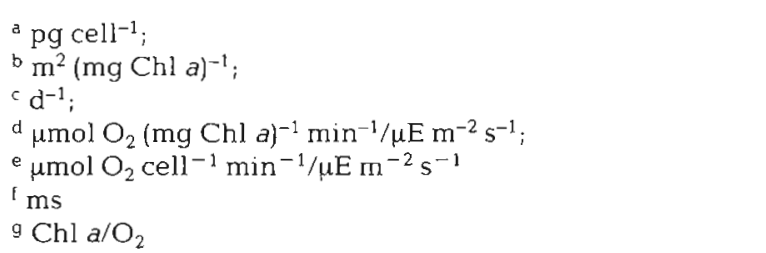 } \\
\hline
\end{tabular}

$\mathrm{Chl}$ a/ $\mathrm{O}_{2}$ for $\mathrm{HL}$ cells, respectively. Since $\mathrm{PSU}_{\mathrm{O}_{2}}$ sizes were not markedly different for $\mathrm{HL}$ and $\mathrm{LL}$, we concluded that Thalassiosira weisflogii adapts to changes in growth irradiance primarily by changing numbers of $\mathrm{PSU}_{\mathrm{O}_{2}}$, and by extension, the number of PS II reaction centers cell ${ }^{-1}$ (see Falkowski et al. 1981 for discussion). 


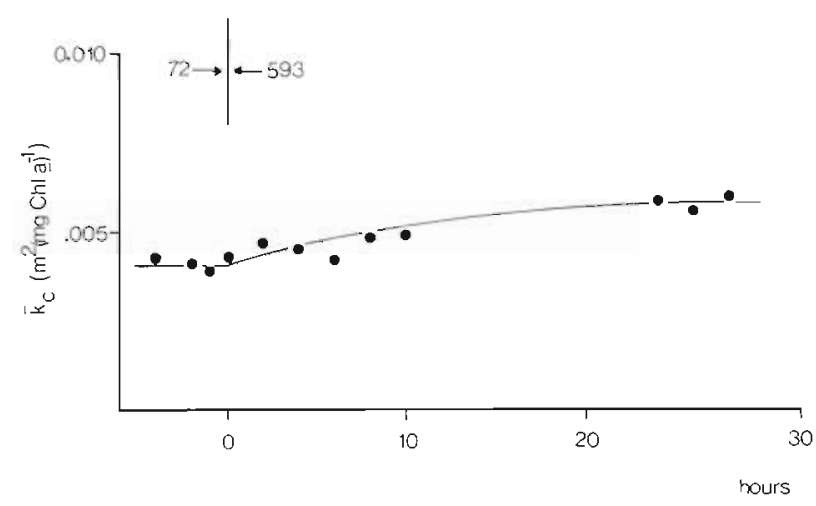

Fig. 2. Thalassiosira weisflogii. Changes in the spectrally averaged light attenuation coefficient, $\mathrm{k}_{c^{\prime}}$ after an increase in growth irradiance from 72 to $593 \mu \mathrm{E} \mathrm{m}^{-2} \mathrm{~s}^{-1}$

\section{Low- to high-light transition}

Following a 1-step change in growth irradiance, from 72 to $593 \mu \mathrm{E} \mathrm{m} \mathrm{m}^{-2} \mathrm{~s}^{-1}(\mathrm{~L} \rightarrow \mathrm{H})$, Chl a cell ${ }^{-1}$ decreased as growth accelerated (see Post et al. 1984). The Chl a specific light attenuation coefficient, $\mathrm{k}_{c}$ or absorption cross-section, increased from $0.0038 \mathrm{~m}^{2}(\mathrm{mg}$ $\mathrm{Chl} \mathrm{a})^{-1}$ at LL to $0.0058 \mathrm{~m}^{2}$ ( $\left.\mathrm{mg} \mathrm{Chl} \mathrm{a)}\right)^{-1}$ at HL (Fig. 2). $\mathrm{K}_{\mathrm{c}}$ changed inversely to $\mathrm{Chl}$ a cell ${ }^{-1}$, and the time scale of adaptation was essentially the same for both processes $(\sim 20 \mathrm{~h})$. The product of $\mathrm{k}_{\mathrm{c}}$ and Chl a cell ${ }^{-1}$ provides an estimate of the apparent in vivo absorption cross-section of the cells, having units of $\mathrm{m}^{2}$ cell-1. The in vivo absorption cross-sections were $0.35 \times 10^{-4}$ $\mathrm{m}^{2}$ cell ${ }^{-1}$ and $0.23 \times 10^{-4} \mathrm{~m}^{2}$ cell $^{-1}$ for $\mathrm{LL}$ and $\mathrm{HL}$ cells, respectively. The ratio of $\mathrm{LL} / \mathrm{HL}$ cellular $\mathrm{Chl} a$ was 2.1. Thus, the ability of the cells to harvest light is 1.5 times higher in LL adapted cells compared with HL adapted cells, however the change in apparent absorption cross-section is not proportional to the increase of the Chl a content.

Changes both in $\overline{\mathrm{K}}_{\mathrm{c}}$ and $\mathrm{PSU}_{\mathrm{O}_{2}}$ during the $\mathrm{L} \rightarrow \mathrm{H}$ transition were related to changes in the photosynthesis-irradiance relation. We calculated the initial slope of P-I curves, $\alpha$, and the minimal turnover time, $\tau$, of a PSU $\mathrm{O}_{2}$. Fig. 3 shows that $\alpha$ and $\tau$ decreased during the $\mathrm{L} \rightarrow \mathrm{H}$ transition. A new steady state $\alpha$ was reached within $8 \mathrm{~h}$. The change in $\alpha$ occurred faster than in Chl a cell ${ }^{-1}$ or $\mathrm{k}_{c}$,

The 2 major pools of carbon in Thalassiosira weisflogii, carbohydrate and protein, responded quite differently during the $\mathrm{L} \rightarrow \mathrm{H}$ transition (Fig. 4). The carbohydrate pool reached a maximum after $8 \mathrm{~h}$ and declined thereafter, reaching a new steady-state level after $24 \mathrm{~h}$. Specifically, cellular carbohydrate increased 10 -fold in $8 \mathrm{~h}$, overshooting the steady-state level at high light by $15 \%$. Protein cell ${ }^{-1}$ was relatively constant immediately after the change in light

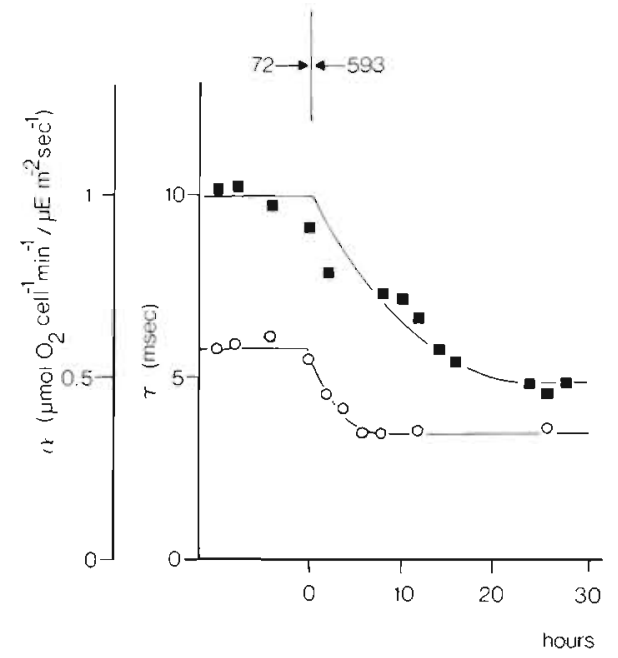

Fig. 3. Thalassiosira weisflogii. Changes in the photosynthetic characteristics $\alpha(0)$ and $\tau(\boldsymbol{\square})$ after an increase in growth irradiance from 72 to $593 \mu \mathrm{E} \mathrm{m}^{-2} \mathrm{~s}^{-1}$

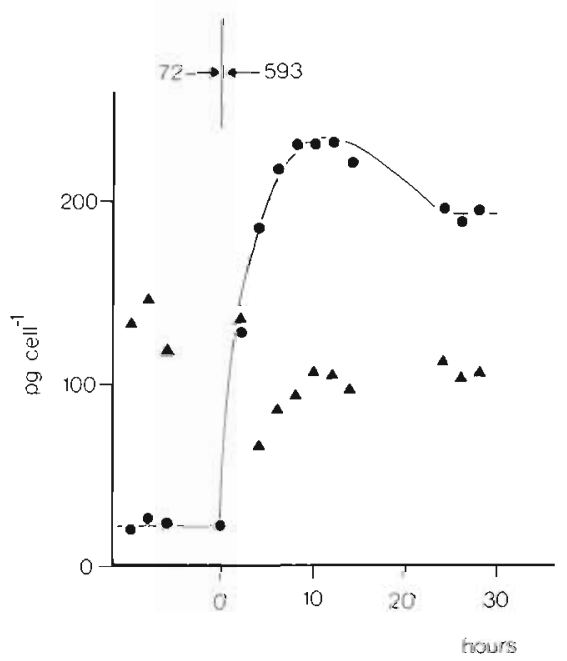

Fig. 4. Thalassiosira weisflogii. Changes in the cellular pool sizes of proteins ( $\mathbf{\Delta})$ and carbohydrates $(\bullet)$ after an increase in light intensity from 72 to $593 \mu \mathrm{E} \mathrm{m}^{-2} \mathrm{~s}^{-1}$

irradiance, however, after $2 \mathrm{~h}$ it decreased $50 \%$ and then increased rapidly again to a new steady-state value, close to the initial value. These results suggest that following the $\mathrm{L} \rightarrow \mathrm{H}$ transition, most of the carbon fixed by the cells was directed into the carbohydrate pool. As $\mu$ reaches a new steady state at $\mathrm{HL}$, the carbohydrate/protein ratio is 5- to 6-fold higher than previously at LL.

\section{High- to low-light transition}

Changing growth irradiance from 593 to $72 \mu \mathrm{E}$ $\mathrm{m}^{-2} \mathrm{~s}^{-1}(\mathrm{H} \rightarrow \mathrm{L})$ was characterized by an immediate sharp drop in growth rate and a slow increase in Chl a 


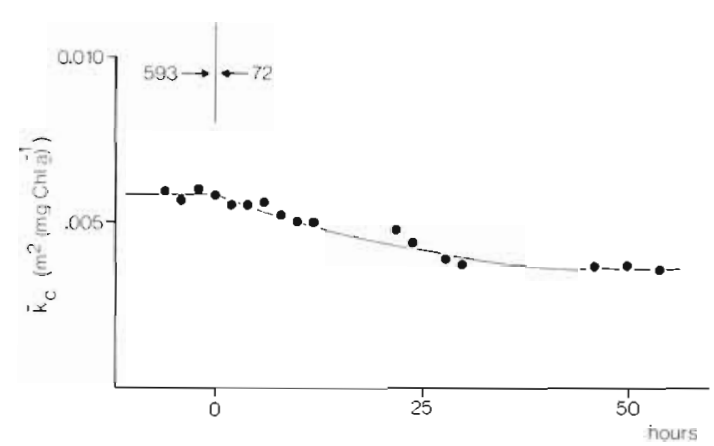

Fig. 5. Thalassiosira weisflogii. Changes in the spectral averaged light attenuation coefficient $\mathrm{k}_{c}$ after a decrease in growth irradiance from 593 to $72 \mu \mathrm{E} \mathrm{m}^{-2} \mathrm{~s}^{-1}$

cell ${ }^{-1}$ (see Post et al. 1984). Although the light-harvesting capacity increased per cell, due to the increase in pigment contents, the $\mathrm{Chl}$ a specific absorption coefficient, $k_{c}$ decreased until a new steady state was reached after $50 \mathrm{~h}$ (Fig. 5). As Thalassiosira weisflogii adapted to decreased light there was an increase in $\alpha$, which reached a new steady state long before $\bar{k}_{c}$ and Chl a cell ${ }^{-1}$ (Fig. 6). The light saturated turnover time, $\tau$, was $\sim 4 \mathrm{~ms}$ for the first $30 \mathrm{~h}$ after the change in light, after which it increased to $\sim 10 \mathrm{~ms}$ (Fig. 6).

Changes in pigment contents and photosynthetic rates following the $\mathrm{H} \rightarrow \mathrm{L}$ transition did not prevent a sharp decrease in division rates, especially during the first $15 \mathrm{~h}$ following the transition. During this initial period, cellular carbohydrate contents decreased markedly, while protein cell ${ }^{-1}$ remained relatively constant (Fig. 7). Carbohydrate cell $^{-1}$ reached its minimum level after $15 \mathrm{~h}$. Protein cell ${ }^{-1}$ decreased slightly during the next $15 \mathrm{~h}$, after both $\alpha$ and carbohydrate cell ${ }^{-1}$ had reached steady state.

\section{Kinetics of adaptation to growth irradiance}

With the exception of cellular protein, the growthirradiance-dependent changes in all parameters studied during both $\mathrm{H} \rightarrow \mathrm{L}$ light and $\mathrm{L} \rightarrow \mathrm{H}$ light transitions were analyzed using a first order kinetic model (Falkowski 1984). In this analysis the following equation is used:

$$
A_{1}=\left(A_{0}-A_{\infty}\right)^{-k t}+A_{\infty}
$$

where $A_{t}=$ a process-variable at time $t_{i} A_{0}$ and $A_{\infty}=$ initial and final levels of the process-variable $A_{i} k=$ first order rate constant having units of $h^{-1}$. It should be noted that rate constants have a sign implicitly associated with them. When a process leads to an accumulation of a product (e.g. carbohydrate) or an increase in a rate (e.g. $\tau$ ), the rate constant is positive. Conversely, when process leads to a depletion of a pool

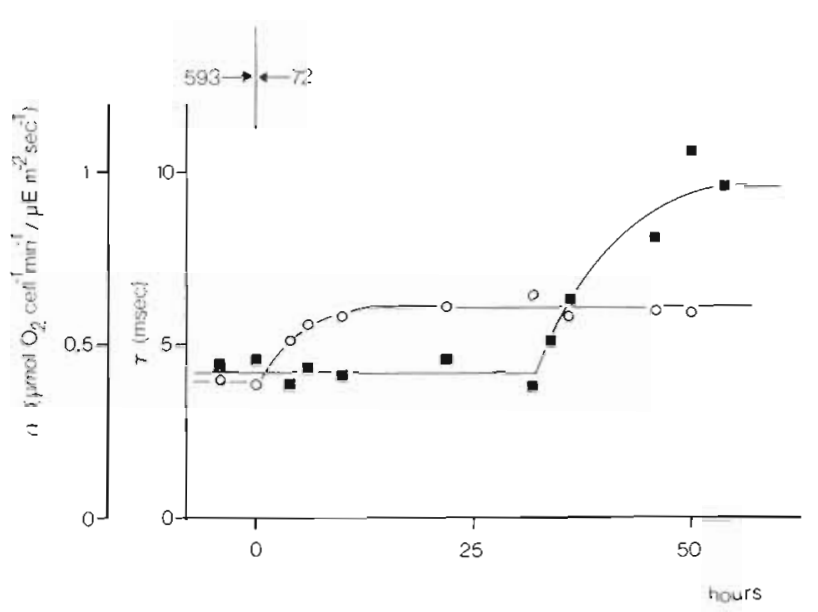

Fig. 6. Thalassiosira weisflogii. Changes in the photosynthetic characteristics $\alpha(O)$ and $\tau(\square)$ after a decrease in growth irradiance from 593 to $72 \mu \mathrm{E} \mathrm{m}^{-2} \mathrm{~s}^{-1}$

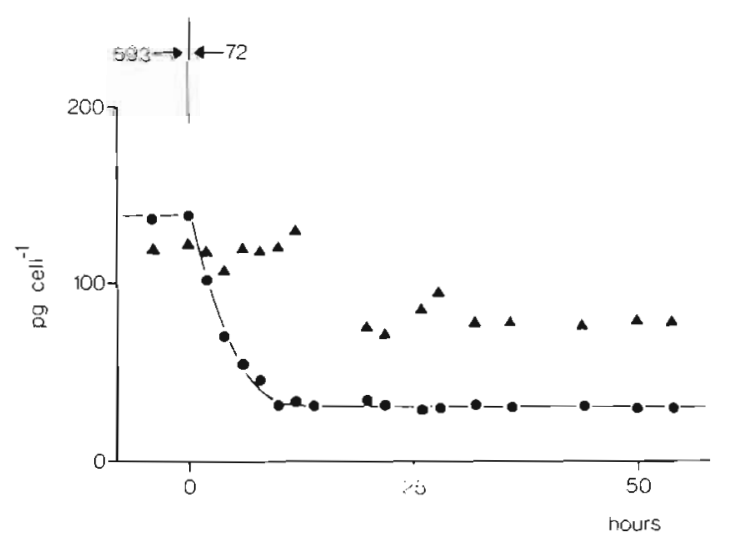

Fig. 7. Thalassiosira weisflogii. Changes in the cellular pool sizes of proteins ( 4 ) and carbohydrates ( $\bullet$ after a decrease in growth irradiance from 593 to $72 \mu \mathrm{E} \mathrm{m} \mathrm{m}^{-2} \mathrm{~s}^{-1}$

or deceleration of a rate the rate constant is negative. Calculated first order rate constant ( $k$ values) for the changes in the various parameters for both transient states are presented in Table 2 .

During the $\mathrm{L} \rightarrow \mathrm{H}$ transition $\mu, \mathrm{Chl} \mathrm{a} \mathrm{cell}{ }^{-1}$, and $\mathrm{K}_{\mathrm{c}}$ all have similar rates of change. Rate constants for the photosynthetic parameters $\alpha$ and $\tau$ are similar to each other but are 3 to 4 times faster than those calculated for $\mu, \bar{k}_{c}$ or Chl a cell ${ }^{-1}$. The highly dynamic nature of the carbohydrate pool is reflected in its rate of change, which is $\sim 2.5$ times higher than those of $\alpha$ and $\tau$.

During the $\mathrm{H} \rightarrow \mathrm{L}$ transition division rate and carbohydrate cell ${ }^{-1}$ changed fastest. The decrease in protein cell ${ }^{-1}$ during the $\mathrm{H} \rightarrow \mathrm{L}$ transition was very small and could not be fitted to first order kinetics with any degree of confidence. The slowest rates of measurable change were observed for $\mathrm{Chl}$ a cell ${ }^{-1}$ and $\mathrm{K}_{c}$ in the $\mathrm{H} \rightarrow$ L transition. 


\section{DISCUSSION}

Our results show that during growth irradiance transitions in Thalassiosira weisflogii, (a) the carbohydrate pool is highly dynamic; (b) the time scales of change in photosynthetic parameters and $\mathrm{Chl} \mathrm{a} \mathrm{cell-1}$ are different and (c) there may be a delay before a change in a pool or a rate is observed (see also Rivkin et al. 1982a).

Before discussing the relation of these observations to each other and to the overall metabolism of the cell, we would like to briefly discuss the distinctions between pools, rates, and changes in pools or rates. These concepts, which are often clear in the steadystate, may be confusing in analysis of data in transition studies. A pool has dimensions of mass or weight, which may be normalized to cell number or Chl $a$ or any other convenient timeless unit (e.g. liter, area, etc.). A rate or flux has a dimension in time. During steady-state balanced growth the pools of all cell constituents are time invariant. Under these conditions the net flux of material into a pool is equal to the growth rate, but the actual flux of the pool may be greater than $\mu$ if the pool turns over (e.g. Chl a: Riper et al. 1979). During a transition state, however, a pool may change with time. Under these conditions, the rate of change is a net flux. An analogous situation exists with respect to rates or fluxes in the steady-state. In the steady-state a flux (e.g. growth rate) is time invariant, but during a transition state a rate or flux may change, i.e. a rate may accelerate or decelerate.

In steady state it is not normally possible to infer fluxes from pool sizes. During a transition, however, a change in a pool size is (by definition) a flux and a change in a flux is (by definition) an acceleration or deceleration of a rate. In this study we followed the time dependent changes in 4 pools, carbohydrate, protein, chl $a$, and $\bar{k}_{c}$ (which is not a true 'pool' but an optical property without a time dimension), and 3 fluxes, $\mu, \alpha$, and $\tau$ (note that $\alpha$ is actually a ratio of 2 fluxes).

Since in diatoms the cell-wall polymers do not consist of carbohydrates, almost all carbohydrate can be considered energy and/or carbon storage. During the $\mathrm{L} \rightarrow \mathrm{H}$ transition the carbohydrate pool increased markedly. During this transition period the cell growth rate was accelerating, but not at a rate fast enough to keep pace with the rate of carbohydrate production. In a sense, the cell synthesized 'excess' photosynthate, i.e. it exceeded the rate required for balanced growth. This 'excess' photosynthate was stored in the cells as carbohydrate. During the $\mathrm{H} \rightarrow \mathrm{L}$ transition the carbohydrate pool was reduced immediately after the transition to the new light regime while initially protein cell ${ }^{-1}$ remained constant. Protein cell ${ }^{-1}$ started to decrease only after carbohydrate cell $^{-1}$ reached its minimum level. The relation between the carbohydrate and protein pools in the $\mathrm{H} \rightarrow \mathrm{L}$ transition suggests that carbohydrates were initially used as an energy source and used for protein synthesis. After carbohydrate cell-1 reached a minimum level, both carbohydrate and protein pools depended solely on the flux of photosynthate.

The first order rate constants for carbohydrate cell ${ }^{-1}$ imply that carbohydrate pools underwent the fastest change during the $\mathrm{L} \rightarrow \mathrm{H}$ transition. This indicates that carbohydrate accumulation in Thalassiosira weisflogii can occur at a much higher rate than respiratory processes can catabolize this pool. The dynamics in the carbohydrate pools can be advantageous for $T$. weisflogii in environments with rapidly changing light conditions, as been suggested by Post et al. (1984). In both $\mathrm{H} \rightarrow \mathrm{L}$ and $\mathrm{L} \rightarrow \mathrm{H}$ transition states the carbohydrate pool served as an energy reserve or buffer, allowing $T$. weisflogii to store photosynthetically available radiation when abundant and providing an energy source, and thus time to adapt, when growth irradiances were reduced.

Unlike the carbohydrate pool, Chl underwent proportionally much smaller changes and these changes were slower. In vivo chlorophylls as well as the other pigments involved in light harvesting are associated with specific proteins and organized in membranes. During a growth-irradiance transition, the assembly of pigment-protein complexes into functional photosynthetic 'units' in thylakoid membranes does not necessarily occur on the same time scale as the synthesis of the pigment-protein complexes per se. Our previous analysis of changes in $\mathrm{Chl}$ suggested that during a $\mathrm{L} \rightarrow \mathrm{H}$ transition the decrease in cellular $\mathrm{Ch}$ could be explained solely by dilution due to cell division (i.e. the first order rate constants for changes in Chl a cell ${ }^{-1}$ and $\mu$ are equal but of opposite signs).

The HL-adapted cells have fewer stacked thylakoids in their chloroplasts than their shade-adapted counterparts (Fig. 8). Our data suggest that a measure of the relative degree of thylakoid stacking is the in vivo Chl specific light absorption coefficient, $\bar{k}_{\mathrm{c}}$ (Falkowski et al. 1985). As ChI a cell ${ }^{-1}$ decreased, $\bar{k}_{c}$ increased, and during the $\mathrm{L} \rightarrow \mathrm{H}$ transition these processes occurred at similar (but not identical) rates. It is tempting to conclude that the slower process (i.e. changes in $\mathrm{k}_{\mathrm{c}}$ ) results from the reorganization of thylakoid membranes within the chloroplast.

In contrast, during a $\mathrm{H} \rightarrow \mathrm{L}$ transition, new $\mathrm{Chl}$ proteins must be synthesized. In Thalassiosira weisflogii this process is relatively slow. Changes in $\mathrm{k}_{c}$ occur at a rate almost an order of magnitude faster than the change in Chl a cell ${ }^{-1}$ (Table 2). These results suggest that reorganization of thylakoids during a $\mathrm{H} \rightarrow \mathrm{L}$ tran- 

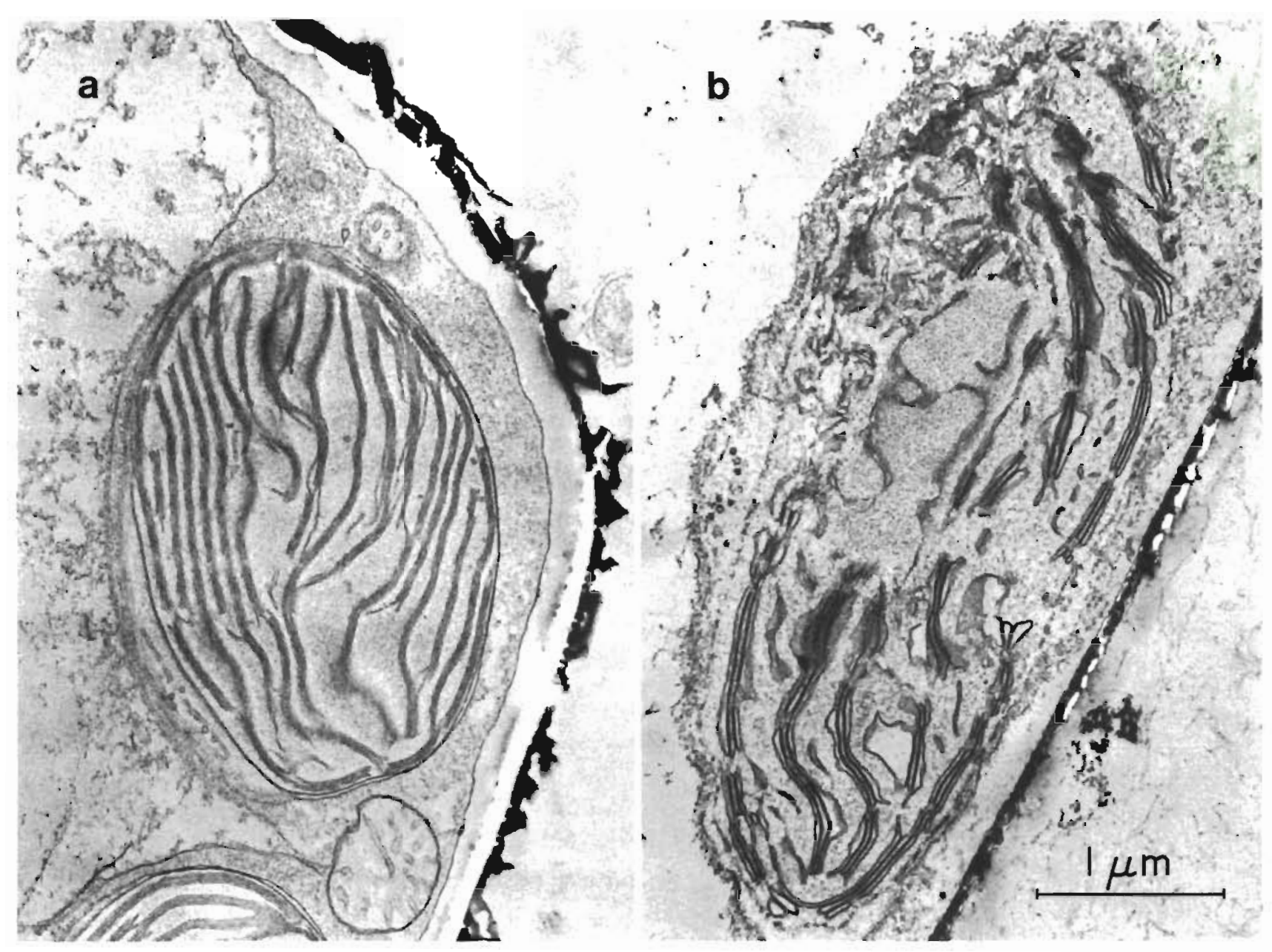

Fig. 8. Thalassiosira weisflogii. Transmission electron micrographs of sections through LL (a) and HL (b) adapted chloroplasts. Note that thylakoid stacking is greater in LL chloroplasts than in HL, but chloroplast volume is lower in LL

sition may preceed the synthesis of Chl. These hypotheses, developed from physiological and biochemical data, should be examined in future studies by following the time course of ultrastructional change in cell chloroplasts.

Changes in $\overline{\mathrm{k}}_{\mathrm{c}}$ are related to the initial slope of the photosynthesis-irradiance curve by the relation:

$$
\alpha^{\prime}=\Phi \overline{\mathrm{k}}_{\mathrm{c}}
$$

where $\alpha^{\prime}$ is expressed on a Chl basis and $\Phi$ is a quantum yield. In this study $\alpha$ was measured by following changes in $\mathrm{O}_{2}$ cell ${ }^{-1}$ as a function of irradiance.

During the $\mathrm{H} \rightarrow \mathrm{L}$ transition $\alpha$ increased while during the $\mathrm{L} \rightarrow \mathrm{H}$ transition it decreased. The changes in $\alpha$ were accompanied by inverse changes in $\mathrm{K}_{c}$, however changes in $\mathrm{k}_{\mathrm{c}}$ were not sufficient to offset apparent changes in the minimum quantum requirement for $\mathrm{O}_{2}$. The changes in $\alpha$ were not solely due to changes in $\mathrm{k}_{c}$, but also resulted from changes in the minimum quantum yield for $\mathrm{O}_{2}$. At least 2 hypotheses, not mutually exclusive, can be proposed to account for the changes in $\alpha$. Firstly, in HL-grown cells, accessory pigments (e.g. $\beta$-carotene) are produced which absorb visible light and serve to protect the cell from photoinhibition but which do not contribute to photochemistry. In the $\mathrm{H} \rightarrow \mathrm{L}$ transition such accessory pigments are broken down rapidly. Secondly, at HL the proportion of excitation energy directed towards PS I is larger than in LL grown cells (Dubinsky et al. 1985). The fraction of excitation energy directed towards PS II or PS I may be regulated by irradiance, e.g. through movement of antennae Chl proteins within a thylakoid (see Bennett 1980 for review). Whatever the mechanisms, it is clear that the changes in a are not simply due to change in Chl a cell ${ }^{-1}$ or $\bar{k}_{\mathrm{c}}$ but reflect more fundamental and subtle changes at the biophysical and molecular levels in the photosynthetic apparatus.

From our results we can develop a working model of the events occuring during a $\mathrm{L} \rightarrow \mathrm{H}$ or $\mathrm{H} \rightarrow \mathrm{L}$ transition in Thalassiosira weisflogii. Light provides an electron flux in the photosynthetic apparatus. As a first approximation this flux is simply related to $\mathrm{O}_{2}$ produc- 
tion, i.e. the rate of $\mathrm{O}_{2}$ evolution gives a measure of the rate at which electrons are moved from PS II to PS I. Inevitably the electrochemical gradient established in a given photon flux is used to generate ATP and reductant, and, as correlary, the rate of formation of ATP and reductant is directly but non-linearly related to the photon flux. The capacity for a cell to store ATP and reductant (e.g. NADPH, ferredoxin) is limited.

When cells are grown at low irradiance levels and brought to high irradiance levels, ATP and NADPH production exceeds the rate required to reduce $\mathrm{CO}_{2}$ or $\mathrm{NO}_{3}^{-}$or form macromolecules to maintain a steadystate growth rate. In the absence of $\mathrm{CO}_{2}$ or other nutrient limitation, ATP and reductant are used to reduce $\mathrm{CO}_{2}$ in 'excess', forming carbohydrate. The carbohydrate pool rapidly accumulates. This pheomenon is sometimes called 'overflow' metabolism (see Myers 1980). As carbohydrates accumulate, more $\mathrm{NO}_{3}^{-}$may be reduced, leading to the potential synthesis of protein. At this point the mechanisms by which protein synthesis are enhanced are unclear, however because the first order rate constants for $\mu$ exceed change in protein cell ${ }^{-1}$, we hypothesize that translation of mRNA is enhanced by a $\mathrm{L} \rightarrow \mathrm{H}$ transition. Growth and division are not necessarily coupled during this transition period. We observed that protein cell $^{-1}$ decreased by $50 \% 2 \mathrm{~h}$ after a $\mathrm{L} \rightarrow \mathrm{H}$ transition, suggesting a sudden, synchronous division. That cell protein returned rapidly to its initial value suggests that the new steady-state growth rate was closely coupled to the rate of protein synthesis. The data also indicate that during a $\mathrm{L} \rightarrow \mathrm{H}$ transition cells are not in 'balanced' growth, e.g. the rate of synthesis of carbohydrate exceeds that of protein.

As cell division proceeds in a $\mathrm{L} \rightarrow \mathrm{H}$ transition, $\mathrm{Chl} \mathrm{a}$ cell $^{-1}$ is reduced (see Post et al. 1984). The reduction of $\mathrm{Chl} a$ cell $^{-1}$ is accompanied by a decrease in $\tau$. At HL the cells are at, or close to, light saturation of photosynthesis. Over-excitation of PS II could lead to photoinhibition, especially if the ultimate recipient of reductant (e.g. $\mathrm{CO}_{2}$ or $\mathrm{NO}_{3}^{-}$) is limiting. The cell appears to overcome the problem of balancing photon input with electron flow by decreasing light harvesting potential and increasing the rate at which electrons can be moved from $\mathrm{H}_{2} \mathrm{O}$ to $\mathrm{CO}_{2}$. Again, at present, we do not know exactly how this is achieved. One obvious mechanism is by increasing the synthesis of a rate limiting electron carrier in the photosynthetic apparatus. Preliminary results with polyclonal antibodies indicate that this may be via increased synthesis of RUBPcase (Bennett \& Falkowski unpubl.).

When HL-grown cells are transferred to LL, photosynthetic electron flow decreases in proportion to the difference in photon flux densities. The rate of production of ATP and reductant from photosynthetic electron flow is reduced, yet the cell still contains high levels of mRNA and high demand for macromolecules. To offset the energy crisis, carbohydrates are catabolized; nevertheless, cell growth rates decrease markedly. In some species, however, growth appears to be maintained for considerable periods (Rivkin et al. 1982b). As cell growth decreases the Chl a pool increases, leading to an increased potential to harvest light. Only as a last resort is protein used for an energy source. It should be pointed out that the types and number of various proteins synthesized in HL and LL are different. At LL the Chl proteins are synthesized to a greater extent than in HL cells, while the situation for RUBPcase is just the opposite (Falkowski unpubl.).

In temperate and tropical latitudes, natural phytoplankton assemblages undergo $\mathrm{H} \rightarrow \mathrm{L}$ and $\mathrm{L} \rightarrow \mathrm{H}$ light transitions daily (or more frequently if mixing is great) (see Falkowski 1984 for review). Under such circumstances the fluctuation in carbohydrate and protein pools, reported here for a relatively long time scale observation, are also observed on the diel time scale (Cuehel et al. 1984, Post et al. 1985). However, cells appear to distinguish between light/dark cycles and variations in light irradiance (Post et al. 1984); cells do not 'shade' adapt at night. This paradox suggests that light-shade adaptation is not simply a consequence of post-translational control resulting from overflow metabolism, but is controlled at the translational and transcriptional levels, involving light dependent controls on protein synthesis.

Acknowledgements. We thank Dr. Myron Ledbetter of the Biology Department at Brookhaven National Lab for the electron microscopy and Linda Benson for technical assistance. This research was performed at Brookhaven National Laboratory under the anspices of the U.S. Department of Energy under Contract No. DE-AC02-76CH00016.

\section{LITERATURE CITED}

Atlas, D., Bannister, T T (1980). Dependence of mean spectral extinction coefficient of phytoplankton on depth. water color and species. Limnol. Oceanogr 25: 157-159

Bennett, J. (1980). Chloroplast protein phosphorylation and the regulation of photosynthesis. Physiol. Plant. 60: 583-590

Bradford, $M$. (1976). A rapid and sensitive method for the quantitation of microgram quantities of protein utilizing the principle of protein-dye binding. Analyt. Biochem. 72 : 248-254

Cuehel, R. L., Ortner, P. B., Lean, D. R. S. (1984). Night synthesis of protein by algae. Limnol. Oceanogr 29: $731-744$

Dubinsky, Z., Berman, T., Schanz, F. (1984). Field experiments for in situ measurements of photosynthetic efficiency and quantum yield. J. Plankton Res. 6 (2): 339-349

Dubinsky, Z., Wyman, K., Falkowski, P. G. (1985). Light harvesting and utilization by phytoplankton. Plant Cell Physiol. (in press) 
Falkowski, P. G. (1980). Light-shade adaptation in marine phytoplankton. In: Falkowski, P. G. (ed.) Primary productivity in the sea. Plenum Press, New York, p. 99-119

Falkowski, P. G. (1984a). Kinetics of adaptation to irradiance in Dunaliella tertiolecta. Photosynthetica 18: 62-68

Falkowski, P. G. (1984b). Physiological responses of phytoplankton to natural light regimes. J. Plankton Res. 6: 295-307

Falkowski, P. G., Owens, T. G., Ley, A. C., Mauzerall, D. C. (1981). Effects of growth irradiance levels on the ratio of reaction centres in two species of marine phytoplankton. Pl. Physiol., Wash. 68: 969-973

Falkowski, P. G., Dubinsky, Z., Santostefano, G. (1985). Lightenhanced dark respiration in phytoplankton. Verh. int. Verein. Limnol. (in press)

Guillard, R. R. L., Ryther, J. H. (1962). Studies of marine planktonic diatoms Cyclotella nana (Hustedt) and Detonula confervacea (Cleve) Grun. Can. J. Microbiol. 8: 229-239

Herbert, D., Phipps, P. J., Strange, R. E. (1971). Chemical analysis of microbial cells. In: Norris, J. R., Ribbons, D. W. (ed.) Methods in microbiology, Vol. VB. Academic Press, London, p. 209-344

Jassby, A. D., Platt, T. (1976). Mathematical formulation of the relationship between photosynthesis and light for phytoplankton. Limnol. Oceanogr. 21 (4): 540-547

Jeffrey, S. W., Humphrey, G. W. (1975). New spectrophotometric equations for determining chlorophylls $a, b$ $c_{1}$, and $c_{2}$ in higher plants, algae and natural phytoplankton. Biochem. Physiol. Pflanz. 167: 191-194

Loogman, J. G. (1982). Influence of photoperiodicity on algal growth kinetics. Ph.D. thesis, Univ. of Amsterdam

Marra, J. (1980). Time course of light intensity adaptation in a marine diatom. Mar. Biol. Lett. 1: 175-183
Myers, J. (1980). On the algae: thoughts about physiology and measurements of efficiency. In: Falkowski, P. G. (ed.) Primary productivity in the sea. Plenum Press, New York, p. $1-16$

Myers, J., Graham, J. (1971). The photosynthetic unit in Chlorella measured with repetitive short flashes. Pl. Physiol., Wash. 48: 282-286

Post, A. F., Dubinsky, Z., Wyman, K., Falkowski, P. G. (1984). Kinetics of light intensity adaptation in a marine planktonic diatom. Mar. Biol. 83: 231-238

Post, A. F., Loogman, J. G., Mur, L. R. (1985). Regulation of growth and photosynthesis by Oscillatoria agardhii grown with a light dark cycle. FEMS Microbiol. Ecol. 31 (2): 97-102

Prezelin, B. B., Matlick, H. A. (1980). Time courses of photoadaptation in the photosynthesis irradiance relationship of a dinoflagellate exhibiting photosynthetic periodicity Mar. Biol. 58: 85-96

Richardson, K., Beardall, J., Rowen, J. A. (1983). Adaptation of unicellular algae to irradiance: an analysis of strategies. New Phytol. 93: 157-191

Riper, D. M., Owens, T. G., Falkowski, P. G. (1979). Chlorophyll turnover in Skeletonema costatum, a marine plankton diatom. Pl. Physiol., Wash. 64: 49-54

Rivkin, R. B., Seliger, H. H., Swift, E., Biggley, W. H. (1982a). Light-shade adaptation by the oceanic dinoflagellates Pyrocystis noctiluca and $P$. fusiformis. Mar. Biol. 68: 181-191

Rivkin, R. B., Voytek, M. A., Seliger, H. H. (1982b). Phytoplankton division rates in light-limited environments: two adaptations. Science 215: 1123-1125

Tolbert, N. E. (1974). Photorespiration. In: Stewart, W. D. P. (ed.) Algal physiology and biochemistry. Blackwell, Oxford, p. 474-504 